\title{
The National Ignition Facility (NIF) A Path to Fusion Energy
}

E. Moses

November 27, 2006

ICENES 2007

Istanbul, Turkey

June 3, 2007 through June 8, 2007 
This document was prepared as an account of work sponsored by an agency of the United States Government. Neither the United States Government nor the University of California nor any of their employees, makes any warranty, express or implied, or assumes any legal liability or responsibility for the accuracy, completeness, or usefulness of any information, apparatus, product, or process disclosed, or represents that its use would not infringe privately owned rights. Reference herein to any specific commercial product, process, or service by trade name, trademark, manufacturer, or otherwise, does not necessarily constitute or imply its endorsement, recommendation, or favoring by the United States Government or the University of California. The views and opinions of authors expressed herein do not necessarily state or reflect those of the United States Government or the University of California, and shall not be used for advertising or product endorsement purposes. 


\title{
The National Ignition Facility (NIF): A path to Fusion Energy*
}

\author{
Edward I. Moses \\ Lawrence Livermore National Laboratory, Livermore, CA 94550, moses1@Ilnl.gov
}

Fusion energy has long been considered a promising clean, nearly inexhaustible source of energy. Power production by fusion micro-explosions of inertial confinement fusion (ICF) targets has been a long term research goal since the invention of the first laser in 1960. The NIF is poised to take the next important step in the journey by beginning experiments researching ICF ignition. Ignition on NIF will be the culmination of over thirty years of ICF research on high-powered laser systems such as the Nova laser at LLNL and the OMEGA laser at the University of Rochester as well as smaller systems around the world. NIF is a 192 beam Ndglass laser facility at LLNL that is more than $90 \%$ complete. The first cluster of 48 beams is operational in the laser bay, the second cluster is now being commissioned, and the beam path to the target chamber is being installed. The Project will be completed in 2009 and ignition experiments will start in 2010. When completed NIF will produce up to $1.8 \mathrm{MJ}$ of $0.35 \mu \mathrm{m}$ light in highly shaped pulses required for ignition. It will have beam stability and control to higher precision than any other laser fusion facility. Experiments using one of the beams of NIF have demonstrated that NIF can meet its beam performance goals. The National Ignition Campaign (NIC) has been established to manage the ignition effort on NIF. NIC has all of the research and development required to execute the ignition plan and to develop NIF into a fully operational facility. NIF will explore the ignition space, including direct drive, $2 \omega$ ignition, and fast ignition, to optimize target efficiency for developing fusion as an energy source. In addition to efficient target performance, fusion energy requires significant advances in high repetition rate lasers and fusion reactor technology. The Mercury laser at LLNL is a high repetition rate Nd-glass laser for fusion energy driver development. Mercury uses state-o-the art technology such as ceramic laser slabs and light diode pumping for improved efficiency and thermal management. Progress in NIF, NIC, Mercury, and the path forward for fusion energy will be presented.

* This work was performed under the auspices of the U. S. Department of Energy by the University of California Lawrence Livermore National Laboratory under contract No. W-7405-Eng-48. 